BITTER CARNIVAL 



\section{BITTER CARNIVAL}

RESSENTIMENT

AND THE ABJECT HERO

Michael Andvé Bernstein

PRINCETON UNIVERSITY PRESS PRINCETON, NEW JERSEY 


\section{Copyright $(\subset) 1992$ by Princeton University Press}

Published by Princeton University Press, 41 William Street, Princeton, New Jersey 08540

In the United Kingdom: Princeton University Press, Oxford All Rights Reserved

\section{Library of Congress Cataloging-in-Publication Data}

Bernstein, Michael André, 1947-

Bitter Carnival : ressentiment and the abject

hero/ Michael André Bernstein.

p. $\mathrm{cm}$.

Includes index.

eISBN 1-4008-0069-2

1. Abjection in literature. 2. Heroes in literature. 3. Cynicism in literature. 4. Literature-History and criticism.

I. Title. II. Title: Ressentiment and the abject hero.

PN56.A23B4 1992

$809^{\prime} .93353-\mathrm{dc} 20 \quad 91-25871$ CIP

This book has been composed in Linotron Galliard 
for

ANNA-NORA BERNSTEIN

and

MOSES ELCH BRUGGER

nothing matters but the quality

of the affection 
